\title{
Metoda Audytywno-Werbalna w rehabilitacji stuchu i mowy dzieci z wadą słuchu - historia, zasady i praktyka
}

\section{Auditory-Verbal Therapy in the speech and language therapy of children with hearing deficiencies - history, principles and practice}

\author{
Agnieszka Pankowska ${ }^{1}$, Anna Barej ${ }^{1}$, Agata Lutek ${ }^{1}$, Małgorzata Zgoda², Edyta Zielińska ${ }^{1}$ \\ ${ }^{1}$ Instytut Fizjologii i Patologii Słuchu, Światowe Centrum Słuchu, Klinika Rehabilitacji, Kajetany \\ ${ }^{2}$ Instytut Fizjologii i Patologii Słuchu, Światowe Centrum Słuchu, Zakład Implantów i Percepcji Słuchowej, \\ Kajetany
}

Adres autora: Agnieszka Pankowska, Światowe Centrum Słuchu, Klinika Rehabilitacji, ul. Mokra 17, Kajetany, 05-830 Nadarzyn, e-mail: a.pankowska@ifps.org.pl

\begin{abstract}
Streszczenie
Zastosowanie implantów ślimakowych oraz najnowszych aparatów słuchowych daje małym dzieciom z wadami słuchu możliwości odbioru sygnałów akustycznych w stopniu, który wcześniej był nieosiągalny. Urządzenia te umożliwiają małym pacjentom odbiór sygnałów (słyszenie), a właściwie organizowana i systematycznie prowadzona rehabilitacja pozwala rozwijać słuchanie, nabywanie języka i umiejętność mówienia. Istnieje wiele metod pracy z małymi dziećmi, które stosuje się obecnie. W niniejszym artykule przedstawione zostaną historia, założenia, zasady i praktyka Metody Audytywno-Werbalnej (ang. Auditory-Verbal Therapy, AVT). Jest ona oparta przede wszystkim na kanale słuchowym, a jej nadrzędnym celem jest, by dzieci z wadą słuchu wzrastały w normalnym środowisku (tam, gdzie żyją i uczą się), by uczynić je osobami niezależnymi i biorącymi udział w życiu otoczenia. Środkiem do tak określonego celu jest nauka poprzez słuchanie, bez korzystania z odczytywania mowy z ust, gestów, znaków alfabetu palcowego lub znaków języka migowego. Inspiracją do przedstawienia tych informacji był udział grupy specjalistów z Instytutu Fizjologii i Patologii Słuchu w jedynych w Polsce Międzynarodowych Warsztatach Naukowo-Szkoleniowych dla Terapeutów Mowy „Listening for Life. Auditory-Verbal Therapy: Principles into Practice”, prowadzonych przez prof. Warrena Estabrooksa oraz doświadczenia zdobyte w pracy z małymi dziećmi.
\end{abstract}

Słowa kluczowe: Metoda Audytywno-Werbalna (AVT) • rehabilitacja słuchu i mowy • implanty ślimakowe

\begin{abstract}
Application of cochlear implants and newest hearing aids provides little children with hearing deficiencies with a possibility of receiving the acoustic signals in the hitherto undreamt of extent. These devices give little patients a possibility to receive signals (hearing), and the properly organized and regular rehabilitation allows to develop listening, language and speech acquisition. There is a range of methods of working with little children in use today. This article presents history, guidelines, principles, and praxis of the auditory-verbal method. This method bases primarily on the auditory channel, its major goal is for deaf and hard of hearing children to grow up in normal environment (where they live and learn), to make them independent and active citizens. The way to achieve this goal is learning through listening without using lip-reading, gestures, fingerspelling or sign language. An inspiration for presenting that information has been the participation of the group of specialists from the Institute of Physiology and Pathology of Hearing in the only one in Poland International Scientific - Training Workshop for Speech Therapists "Listening for Life. Auditory-Verbal Therapy: Principles into Practice" conducted by Prof. Warren Estabrooks and experience gained in working with little children.
\end{abstract}

Key words: Auditory-Verbal Therapy $(\mathrm{AVT}) \bullet$ speech and language rehabilitation • cochlear implants

\section{Wprowadzenie}

Rehabilitacja dziecka z wadą słuchu jest procesem. Jest zbiorem oddziaływań, których efektem ma być osiągnięcie przez dziecko umiejętności językowych i komunikacyjnych pozwalających na samodzielne funkcjonowanie w dorosłym życiu. Powodzenie terapii zależy oczywiście od wielu czynników. Zarówno tych wewnętrznych, 
tkwiących w dziecku, jak i zewnętrznych, tj. specjalistów, rodziców, środowiska i właściwie dobranych metod leczenia oraz rehabilitacji. Pojawienie się, a obecnie powszechne stosowanie implantu ślimakowego jako narzędzia, dzięki któremu możemy umożliwić osobie z głęboką wadą słuchu odbiór bodźców akustycznych, stało się wyzwaniem dla całego grona specjalistów (lekarzy, inżynierów klinicznych, logopedów, pedagogów, psychologów). Obserwacje czynione w codziennej praktyce klinicznej oraz zmieniająca się grupa osób, u których można zastosować implant ślimakowy, mobilizuje do aktualizacji różnych działań prowadzonych w ramach pooperacyjnej rehabilitacji. Powinny być one jednak poparte wiedzą i doświadczeniem. Udział grupy specjalistów z Instytutu Fizjologii i Patologii Słuchu w jedynych w Polsce Międzynarodowych Warsztatach Naukowo-Szkoleniowych dla Terapeutów Mowy „Listening for Life. Auditory-Verbal Therapy: Principles into Practice”, prowadzonych w latach 2008-2009 przez prof. Warrena Estabrooksa, pozwolił na zapoznanie się z historią i zasadami Metody Audytywno-Werbalnej oraz sposobem organizacji i prowadzenia zajęć zwłaszcza z najmłodszymi dziećmi. Poniższy artykuł został przygotowany na podstawie materiałów, jakie otrzymali uczestnicy warsztatów, oraz praktyki zdobytej $\mathrm{w}$ pracy z naszymi pacjentami.

\section{Historia podejścia audytywno-werbalnego}

Źródeł powstania podejścia audytywno-werbalnego należy szukać w XIX wieku. W 1895 roku Victor Urbantschitsch, austriacki lekarz otorynolaryngolog, profesor Uniwersytetu Wiedeńskiego, napisał pracę, „Auditory Training for Deaf Mutism and Acquired Deafness". Dowodził w niej, że dzieci głuche posiadają potencjał słuchowy. Jego główny argument brzmiał: „edukacja i w konsekwencji emocjonalna i społeczna adaptacja głuchych może być umożliwiona przez metodyczny i stały trening słuchowy (ćwiczenia), w którym wykorzystuje się wszelkie resztki słuchu, które określił jako uśpiony zmysł” [1]. Metoda Urbantschitscha spotkała się w owych czasach $\mathrm{z}$ dużą rezerwą i sceptycyzmem nauczycieli i wychowawców dzieci z głęboką wadą słuchu, jednak jego działaniami zainteresował się dr Max Goldstein. Był to syn niemieckich emigrantów, którzy osiedlili się w Ameryce. Zasłynął on jako założyciel Central Institute for the Deaf w St. Louis, w którym łączono pracę specjalistów z różnych dziedzin w ramach edukacji dzieci niedosłyszących. Goldstein współpracował z Urbanitschitschem i jego celem stało się przedstawienie podejścia reprezentowanego przez niemieckiego lekarza oraz zainteresowanie większego grona osób faktem, że dzieci z wrodzoną głęboką wadą słuchu mogą, dzięki odpowiedniemu postępowaniu, nauczyć się mówić zrozumiale. Dr Max Goldstein zdobył uznanie za opracowanie "Acoustic Method” (1939) i rozpowszechnianie idei dotyczących „siły słuchania”.

Warto $\mathrm{w}$ tym miejscu wspomnieć, że propagowaniu idei, iż większość dzieci posiada resztki słuchowe, towarzyszyło pojawienie się w latach czterdziestych XX wieku aparatów słuchowych, które pacjenci mogli nosić jako indywidualnie użytkowane urządzenia. Do grona pionierów podejścia audytywno-werbalnego zaczęli dołączać nauczyciele i terapeuci: Daniel Ling i Agnes („Nan”) Philips jako pierwsi w Wielkiej Brytanii i później w Montreal Oral School for the Deaf i na McGill University w Montrealu, w Kanadzie; Doreen Pollack początkowo w Columbia Presbyterian Medical Center w Nowym Jorku i później na University of Denver i Porter Memorial Hospital w Denver oraz Helen Beebe w Nowym Jorku i Easton w Pensylwanii. Opracowując modele postępowania, starali się przede wszystkim rozwijać przekonanie, że wykorzystanie wzmocnionego słuchu może pozwolić głuchym lub niedosłyszącym dzieciom uczyć się słuchać, opanowywać język mówiony i mówić. W kolejnych latach wielu kolegów i studentów Linga, Pollack i Beebe, jak również inni niezależni praktycy i terapeuci odegrali znaczącą rolę w rozwoju podejścia audytywno-werbalnego. Wśród nich znalazła się m.in. Susann Schmid-Giovannini ze Szwajcarii.

W lutym 1978 roku w Easton w stanie Pensylwania odbyła się dwudniowa konferencja, na której wystąpili wspólnie Daniel Ling, Doreen Polack i Helen Beebe. Spotkaniu przewodniczył dr George Fellendorf, były dyrektor naczelny Alexander Graham Bell Association for the Deaf. Wkrótce po tym historycznym spotkaniu został założony International Committee on Auditory-Verbal Communication (ICAVC).

W 1981 roku rada dyrektorów AG Bell Association for the Deaf zaprosiła przedstawicieli ICAVC do współpracy, a w 1986 roku to Komitet Centralny ICAVC głosował za tym, by ustanowić niezależną organizację non profit, której celem będzie wypracowanie sposobów promowania dostępności i efektywności podejścia audytywno-werbalnego. Wtedy właśnie ICAVC przekształcona została w Auditory-Verbal International, Inc (AVI). Obecnie jest ona zintegrowana z AG Bell Academy for Listening and Spoken Language, a jednym $\mathrm{z}$ jej założycieli i kierownikiem jest prof. Warren Estabrooks, przedstawiany również jako światowy ambasador stowarzyszenia Alexander Graham Bell Association for the Deaf and Hard of Hearing.

Uzupełnieniem promowanego przez wspomnianych powyżej specjalistów podejścia do terapii słuchu i mowy dzieci niedosłyszących były i są badania prowadzone w różnych ośrodkach w Stanach Zjednoczonych i Europie. Dowodzą one, że dzieci z głęboką wadą słuchu, które prowadzone są Metodą Audytywno-Werbalną, mogą osiągnąć poziom rozwoju mowy i języka, który pozwala im na funkcjonowanie w społeczeństwie osób komunikujących się językiem mówionym. Wyzwaniem ostatnich lat jest już nie tylko nauka, lecz także utrzymanie odpowiedniego poziomu kompetencji językowych dzieci niedosłyszących, o czym wspominała również prof. Carol Flexer, gość specjalny majowej konferencji zorganizowanej w Światowym Centrum Słuchu w Kajetanach dotyczącej Metody Audytywno-Werbalnej „SŁUCHAM, WIĘC POTRAFIE,” - LISTENING IS „I CAN”, również związana z Academy for Listening and Spoken Language, działającą w ramach Alexander Graham Bell Association for the Deaf and Hard of Hearing.

\section{Filozofia Metody Audytywno-Werbalnej}

Celem Metody Audytywno-Werbalnej jest, by dzieci niedosłyszące wzrastały w naturalnym środowisku (tam, gdzie żyją i uczą się), by uczynić je osobami niezależnymi i biorącymi udział w życiu otoczenia. Filozofia Metody Audytywno-Werbalnej wspiera natomiast podstawowe prawa 
człowieka, gdyż wszyscy, którzy mają różnego stopnia ubytki słuchu, mają prawo do tego, by pozwolić im rozwijać umiejętność słuchania i wykorzystywania komunikacji werbalnej w kontaktach $\mathrm{z}$ rodziną i innymi członkami społeczeństwa.

Filozofia Metody Audytywno-Werbalnej opiera się na 10 zasadach, którymi należy się kierować. Obejmują one podstawowe wymagania, jakie należy stawiać, by osiągnąć oczekiwany rezultat, jakim jest nauka słuchania, przetwarzania języka mówionego i mówienia dzieci z wadą słuchu, posiadających nawet niewielkie, ale właściwie wzmocnione resztki słuchowe.

Poniżej przedstawiono wspomniane zasady wraz z objaśnieniami. Należy podkreślić, że określenie „rodzice” oznacza także: dziadków, krewnych, opiekunów i inne osoby $\mathrm{z}$ otoczenia dziecka, które wchodzą z nim w interakcje [2].

\section{DZIESIEĆ ZASAD PRAKTYKI AUDYTYWNO-WERBALNEJ}

1. Promowanie wczesnego wykrywania uszkodzeń słuchu u noworodków, niemowląt i małych dzieci poprzez jak najszybsze kierowanie ich na badania audiologiczne i do terapii Metodą Audytywno-Werbalną (AVT).

Właściwa, przeprowadzona możliwie jak najwcześniej diagnoza audiologiczna ma kluczowe znaczenie dla całego rozwoju dziecka i postępowania rehabilitacyjnego. Należy pamiętać, że brak stymulacji powoduje deprywację słuchową, a jeśli będzie ona trwała w okresie kilku pierwszych lat życia dziecka, wpłynie to na znaczące opóźnienia w rozwoju języka (w rozwoju odbioru i nadawania). Naturalnym towarzyszem postępowania audiologicznego jest Metoda Audytywno-Werbalna, w której terapeuta może prowadzić rodziców i pomagać im maksymalnie wykorzystać uzyskany wskutek zastosowania aparatów słuchowych i/lub implantów ślimakowych potencjał słuchowy, by nie dopuścić do rozwoju tego opóźnienia.

2. Zalecanie natychmiastowej oceny i zastosowania odpowiedniej, najnowocześniejszej technologii wspomagającej słyszenie, aby uzyskiwać maksymalne korzyści ze stymulacji słuchowej.

Konieczne jest, by po właściwym rozpoznaniu stopnia i rodzaju ubytku słuchu zaopatrzyć dziecko w odpowiednio dobrane urządzenie poprawiające słyszenie i przy systematycznym korzystaniu z niego działać tak, by dziecko zaczęło otrzymywać stymulację słuchową. Dźwięki z otoczenia dziecka, szczególnie dźwięki mowy, muszą zacząć docierać do odpowiednich ośrodków w mózgu, by mógł następować ich rozwój. Wzrost i dojrzewanie drogi słuchowej oraz ośrodków słuchowych w mózgu pomogą dziecku rozwijać umiejętności słuchowe potrzebne do naturalnie brzmiącej komunikacji werbalnej.

Ogromny postęp w technologii aparatów słuchowych i implantów ślimakowych, jaki dokonał się w ostatnich dziesięcioleciach, oraz ulepszenia w parametrach urządzeń skierowane na takie problemy jak: odległość od rozmówcy, słuchanie na tle dźwięków zakłócających, słyszenie kierunkowe i inne, stwarzają możliwość spontanicznego, (incydentalnego) nabywania języka. Okazuje się, że wiele dzieci z głębokim ubytkiem słuchu, kiedy porównuje się ich wiek słuchowy (tj. wiek liczony od chwili ich stałego korzystania z urządzenia umożliwiającego/wspomagającego słyszenie - przyp. autorów), może dorównać słyszącym rówieśnikom w rozwijaniu języka.

3. Doradzanie rodzicom i ich szkolenie w tym, by pomagali swoim dzieciom posługiwać się słuchem jako głównym (najważniejszym, wiodącym) zmysłem przy rozwijaniu języka mówionego, bez wykorzystywania języka migowego i odczytywania mowy $z$ ust.

Rodzice, którzy wybierają terapię Metodą Audytywno-Werbalną, by zapewnić swemu dziecku najbardziej efektywne i pozytywne doświadczenia, podejmują zobowiązanie, iż będą stymulować komunikację werbalną poprzez słuchanie, że staną się aktywnymi słuchaczami i efektywnymi mówcami. Dzieci najlepiej uczą się od rodziców i będą one czuły wsparcie, gdy zobaczą, że rodzice mają zaufanie do ich możliwości słuchowych wspartych odpowiednio dobranymi urządzeniami (aparatami słuchowymi, implantami ślimakowymi lub obydwoma). Ich mowa, rozwijana dzięki słuchaniu, będzie brzmiała naturalnie. Odczytywanie z ust nie wspiera rozwoju słuchowej samokontroli u dzieci. Język migowy jest używany przez te osoby niedosłyszące, które wybrały wzrok jako ich podstawowy sposób odbioru i komunikacji.

4. Doradzanie rodzicom i ich szkolenie w tym, by stawali się głównymi przewodnikami (organizatorami) rozwoju słuchania i języka mówionego swoich dzieci poprzez aktywny, stały i konsekwentny udział w zindywidualizowanej terapii Metodą Audytywno-Werbalną.

Terapeuci Metody Audytywno-Werbalnej są zobowiązani do doradzania, konsultowania i wspierania rodziców, opiekunów i innych członków rodziny. Terapia Metodą Audytywno-Werbalną jest zawsze prowadzona w ramach indywidualnych sesji. Pozwala to zarówno maksymalizować indywidualny rozwój dziecka jako osoby słuchającej i mówiącej, jak i rodziców jako jego najważniejszych nauczycieli, a ponadto umożliwia efektywne podejście diagnostyczne przez koncentrowanie się na specyfice potrzeb danego dziecka i jego rodziców. Podczas sesji terapeuta (poprzez kreatywne wykorzystanie technik, strategii i procedur) demonstruje rodzicom, jak łączyć cele: słuchowy, mowny, językowy, poznawczy i komunikacyjny w czasie naturalnych zabaw $\mathrm{z}$ dzieckiem. Jego sugestie są po to, by podnieść efektywność działań realizowanych następnie w naturalnym otoczeniu dziecka. Kreatywne wykorzystanie jego wiedzy ma pomóc rodzicom w tym, by cele audytywno-werbalne każdej sesji organizowały ich codzienne, rutynowe postępowanie.

5. Doradzanie rodzicom i ich szkolenie w tym, by tworzyli środowisko, które będzie wspierało nabywanie języka mówionego w ramach codziennej aktywności dziecka.

Zadaniem terapeutów Metody Audytywno-Werbalnej jest pomagać rodzicom tworzyć idealne środowisko słuchowe, by odbiór mowy uczynić tak łatwym, jak to tylko możliwe, a używając odpowiednich technik i strategii, przy uwzględnieniu specyficznych słuchowych potrzeb dziecka, rozwijać 
słuchanie i komunikację słowną. Od rodziców natomiast oczekuje się, by - poprzez ćwiczenie tych technik i strategii w czasie sesji - mogli następnie włączać je w codzienne aktywności dziecka. Rodzice muszą uczyć się, jak postępować w swoim otoczeniu, by ich dziecko w pełni uczestniczyło $\mathrm{w}$ codziennych interakcjach $\mathrm{z}$ rówieśnikami, rodziną i innymi członkami społeczności, tak jak czynią to dzieci z prawidłowym słuchem.

6. Doradzanie rodzicom i ich szkolenie w tym, by pomagali swoim dzieciom łączyć słuchanie i język mówiony we wszystkich aspektach życia.

Mimo zastosowania najnowszych urządzeń umożliwiających i/lub wspomagających odbiór sygnałów akustycznych, dzieci niedosłyszące wymagają pomocy i zachęty, aby łączyć słuchanie i język mówiony z ogólnym rozwojem. Jeśli rodzice nauczą się wykorzystywać wrażenia słuchowe, doceniają słuchanie, to będą mogli doświadczać sytuacji, w których ich dziecko stanie się osobą mogącą słyszeć i aktywnie słuchać. Zacznie ono postrzegać siebie jako osobę, „która może słyszeć”, a przecież najwyższym celem rehabilitacji słuchu i mowy z zastosowaniem Metody Audytywno-Werbalnej jest, by dziecko stało się dobrze przystosowaną, dobrze zorganizowaną osobą, która wykorzystuje słuchanie i mówienie do tego, by z powodzeniem wchodzić $\mathrm{w}$ interakcje $\mathrm{z}$ innymi $\mathrm{w}$ domu, w szkole i społeczeństwie.

7. Doradzanie rodzicom i ich szkolenie w tym, by wykorzystywali naturalne wzorce rozwojowe w obszarze: słuchania, mowy, języka, umiejętności poznawczych i komunikacji.

Terapeuci Metody Audytywno-Werbalnej, biorąc pod uwagę słyszenie dziecka, jego wiek rozwojowy i aktualny poziom umiejętności, rozwijają indywidualne programy terapii oparte na naturalnych wzorcach rozwojowych w obszarze: słuchania, mowy, języka, umiejętności poznawczych i komunikacji. Zarówno terapeuta, jak i rodzice będą pomagać dziecku rozwijać umiejętności w tych 5 wspomnianych obszarach w sposób porównywalny do tego, jak rozwijają się one u słyszących rówieśników. Rodzice, dzięki pomocy terapeuty, nauczą się określać cele, które są odpowiednie dla ich dziecka. Należy działać tak, by rozumieli oni, że nowe umiejętności budowane są na wcześniej rozwiniętych umiejętnościach, a cele będą określane tak i po to, by pomóc dziecku odnosić sukces w nauce języka mówionego najszybciej, jak to jest możliwe.

8. Doradzanie rodzicom i ich szkolenie w tym, by pomagali swoim dzieciom w samokontroli języka mówionego poprzez słuchanie.

We wczesnych etapach terapii, kiedy dziecko nie jest jeszcze gotowe, by czynić to samodzielnie, rodzice są zachęcani do naśladowania wokalizacji dziecka. Celem takiego zachowania jest zarówno uzyskiwanie przez dziecko informacji zwrotnej, jak i zachęcanie je do słuchania swoich produkcji wokalnych i podejmowania prób włączania ich do komunikacji. W późniejszym okresie terapii rodzice prezentują odpowiednie wzorce mowy i języka, a dziecko jest zachęcane do słuchania i werbalnego naśladowania, ewentualnie uczone jest modyfikowania swojej własnej mowy. Efektywne słuchanie i modulacja głosu przygotowują dziecko do niezależnej (samodzielnej) komunikacji.

9. Organizowanie systematycznej oceny diagnostycznej w celu rozwijania indywidualnych planów terapii Metodą Audytywno-Werbalną, by monitorować postępy oraz, doskonalić efektywność tych planów dla dziecka i rodziny.

Każdy terapeuta, po stworzeniu planu terapii Metodą Audytywno-Werbalną, musi przeprowadzać bezpośrednią i formalną ocenę diagnostyczną, aby monitorować postępy dziecka i rodziny. Ocena bezpośrednia dokonywana jest w trakcie sesji lub później - dzięki temu, że sesje są nagrywane - na podstawie obserwacji słuchowego, mownego, językowego, poznawczego i komunikacyjnego funkcjonowania dziecka podczas zabaw i zajęć. Ocenę formalną prowadzi się z wykorzystaniem wystandaryzowanych testów, które są zwykle przeprowadzane raz na 6 miesięcy. Warto podkreślić, że terapeuta Metody Audytywno-Werbalnej wykorzystuje zestaw testów opartych na zadaniach dla dzieci z prawidłowym słuchem, a oceniających: słuchanie i umiejętności słuchowe, artykulację, słownictwo bierne i czynne, rozwój umiejętności poznawczych oraz język. Osoby zainteresowane odsyłamy do publikacji „50 FAQ About AVT" [3], w której znajduje się szczegółowy opis testów proponowanych przez twórców Metody Audytywno-Werbalnej.

10. Promowanie od wczesnego dzieciństwa nauki w szkołach powszechnych ze słyszącymi rówieśnikami i z odpowiednim wsparciem ze strony właściwych instytucji (osób).

Powinny funkcjonować odpowiednie instytucje (osoby), które zajmują się przygotowaniem klas integracyjnych, informacjami dla rodziców, nauczycieli szkolnych, kadry nauczycieli, konsultantów itp. Odpowiedni zespół może ustalać, jakie miejsce w klasie jest potrzebne dziecku z wadą słuchu, jakie środowisko edukacyjne lub społeczne jest wskazane, aby mogło ono wykorzystać swój potencjał. Zespół specjalistów - pedagog szkolny we współpracy z rodzicami, nauczycielami oraz terapeutą Metody Audytywno-Werbalnej - powinien pomóc dziecku i zadbać, by jego rozwojowe potrzeby realizowane były w środowisku szkoły integracyjnej.

Przedstawiony powyżej zbiór 10 zasad został przyjęty w dniu 11 stycznia 2006 roku przez AG Bell Academy for Listening and Spoken Language i przestrzegać go powinni wszyscy profesjonaliści, którzy pracują Metodą Audytywno-Werbalną.

\section{Współpraca z rodzicami}

Zgodnie z filozofią Metody Audytywno-Werbalnej osoby uczestniczące w terapii są traktowane na zasadach partnerskich. Oznacza to, że każdy ma prawo przedstawiać swoje argumenty, dzielić się odczuciami, wrażeniami i emocjami. Kreować i współtworzyć strategie, wykorzystywać i modyfikować techniki. Warto jednak zwrócić uwagę na fakt, że jeżeli zasady są źle przekazane i zrozumiane, istnieje ryzyko konfliktu. Praktyka dowodzi, że każda grupa potrzebuje lidera. Obserwując różne zajęcia, nie sposób oprzeć 
się wrażeniu, że w tradycji rehabilitacji dzieci z wadą słuchu proponowanej w wielu placówkach w Polsce liderem jest terapeuta mowy i języka (surdologopeda, logopeda), natomiast dziecko i rodzice są mniej lub bardziej aktywnymi odbiorcami jego pomysłów czy sugestii.

Zasady terapii Metodą Audytywno-Werbalną nakazują nam stanowczą zmianę tego stanu rzeczy. Podczas sesji prowadzonej zgodnie z nimi podział ról najważniejszych uczestników zajęć przedstawia się następująco: terapeuta jest instruktorem i przewodnikiem, liderem są rodzice, a dziecko - angażowane przez nich do współdziałania $-\mathrm{z}$ roli odbiorcy przechodzi do roli partnera $\mathrm{w}$ akcie komunikacji. Wyróżnieniem dla rodziców jest bycie kluczową postacią, która wpływa na zdobywanie przez dziecko znaczącej roli w świecie osób słyszących. Dlatego też, zgodnie z podejściem reprezentowanym w terapii Metodą Audytywno-Werbalną, to RODZICE stają się partnerem (klientem) terapeuty słuchu i mowy. To oni od pierwszych dni spędzają z dzieckiem najwięcej czasu. Poprzez swoje konsekwentne postępowanie w czasie codziennych interakcji mogą organizować mu najlepsze warunki do słuchania i rozwoju języka. To oni będą stałym i niezmiennym ogniwem w kreowaniu jego przyszłości.

Aktywne uczestnictwo rodziców w każdych indywidualnych zajęciach pozwala im praktycznie opanować prezentowane techniki i samodzielnie kreować cele. Rodzice powinni współdziałać $\mathrm{z}$ terapeutą $\mathrm{w}$ dostosowywaniu form zabawy i aktywności do indywidualnych zainteresowań i możliwości dziecka. To oni najlepiej nadają znaczenie pierwszym próbom komunikowania się dziecka. Są partnerami terapeuty w opanowywaniu przez dziecko różnych znaków języka, jak na przykład odpowiadanie na pytania czy zrozumienie sensu zaimków. Wszyscy mogą układać cele terapii dla dziecka, ale tylko rodzice mają w sobie tyle determinacji, by konsekwentnie je realizować.

Ważne, by zrozumieć, że o rozwoju języka dziecka nie decyduje liczba odbytych z nim zajęć "robiąc terapię" czy liczba i jakość zabawek bądź pomocy, którymi dysponujemy. Zabawki w gabinecie służą wyłącznie odtwarzaniu sytuacji, które zdarzają się wokół dziecka na co dzień. Są elementem, a nie podstawą organizacji pracy. Metoda $\mathrm{Au}-$ dytywno-Werbalna nie polega na odtwarzaniu spisanych schematów postępowania, gdyż fundamentem nabywania języka jest jego rozwój poprzez naturalne interakcje z innymi ludźmi, dotyczące spraw ważnych i interesujących dla samego dziecka. Do rodziców należy współpraca $\mathrm{z}$ terapeutą, natomiast rolą dziecka jest bawić się! Rodzice powinni poczuć, że podejście realizujące filozofię Metody Audytywno-Werbalnej obecne jest wszędzie wokół nich: $\mathrm{w}$ parku, w domu, w sklepie, jest po prostu sposobem życia.

Poprzez aktywny udział rodziców w zajęciach terapeuta słuchu i mowy może obserwować ich zaangażowanie, chęć stosowania demonstrowanych technik, sposób pracy, wykorzystywanie języka ciała i wreszcie gotowość rodziców do przeciwdziałania rozwojowi niewłaściwych zachowań dziecka. Rodzice stopniowo, poprzez odgrywanie ról, zmieniają swoją postawę, stają się bardziej naturalni. $\mathrm{W}$ czasie zajęć pojawia się coraz więcej pozytywnych interakcji z dzieckiem. Ono samo zaczyna być bardziej podatne na naukę, uważne i gotowe do współpracy.
Rodzice powinni być instruowani odnośnie technik stosowanych w terapii, tak, by tworząc swój program, stali się prawdziwymi autorami sukcesów dziecka. Instrukcja przekazywana rodzicom podczas sesji powinna być zawsze dostosowana do ich osobowości, sposobu uczenia się, stylu życia, funkcjonowania rodziny, języka. Rodzice uczą się poprzez obserwacje, słuchanie, ale przede wszystkim poprzez wykonywanie zadań. Jeśli program terapii dziecka ma być efektywny, to rodzice nie mogą tylko obserwować, muszą aktywnie w nim uczestniczyć.

\section{Współpraca $\mathrm{z}$ innymi specjalistami}

Terapeuta Metody Audytywno-Werbalnej poprzez aktywną i efektywną współpracę z rodzicami tworzy wraz z nimi rodzaj zespołu. Mogą i powinni dołączyć do niego także inni członkowie. Ważne, by wszyscy respektowali prawo rodziców do dokonywania wyborów drogi rehabilitacji i edukacji dziecka oraz uwzględniali specyficzne potrzeby tej konkretnej rodziny. Członkami zespołu w terapii prowadzonej Metodą Audytywno-Werbalną są rodzice, terapeuta słuchu i mowy, audiolog, otolaryngolog, protetyk słuchu lub inżynier kliniczny (stosownie do urządzeń, z jakich dziecko korzysta), nauczyciel i inni członkowie rodziny. Jeżeli dziecko wymaga pomocy dodatkowej, do zespołu dołączyć mogą psycholog, logopeda (rozumiany jako specjalista od pracy nad artykulacją), specjalista wczesnej interwencji, pracownik socjalny itp. Te osoby nie odpowiadają za organizację terapii Metodą Audytywno-Werbalną, ale ich wsparcie, zrozumienie zasad i zaangażowanie tworzą i wzmacniają zespół.

\section{Środowisko słuchowe}

Wspomniano już, że zgodnie z zasadami praktyki Metody Audytywno-Werbalnej zarówno terapeuci, jak i rodzice zobowiązani się do wykorzystywania kanału słuchowego do rozwoju mowy, języka i komunikacji werbalnej. Zobowiązani są także do kreowania otoczenia, w którym słuchanie będzie przyjemne dla dziecka. Realizacji takich założeń służą następujące zasady:

- podczas zajęć należy zawsze eliminować zakłócające dźwięki tła,

- należy mówić możliwie blisko mikrofonu aparatu słuchowego i/lub implantu ślimakowego,

- dziecko zawsze siedzi pomiędzy prowadzącym zajęcia a matką/ojcem,

- rozmowa prowadzona jest spokojnym, naturalnie brzmiącym głosem,

- mowa powinna być pełna powtórzeń, melodii, ekspresji, rytmiczna.

\section{Techniki i strategie Metody Audytywno-Werbalnej}

Są to zachowania i reguły, używane i prezentowane w czasie sesji, których uczymy rodziców, by oni sami mogli je stosować w codziennych zabawach z dzieckiem. Należą do nich m.in.:

- pozyskiwanie uwagi dziecka poprzez słuchanie dźwięków przedmiotowych i mowy,

- prezentowanie zabawki, desygnatu, korzystając z możliwości słuchowego odbioru informacji przez dziecko (zgodnie z zasadą: najpierw dźwięk potem obraz), 
- tylko jedna osoba mówi w danym momencie,

- modelowanie właściwego użycia wzorców językowych (melodia, intonacja, akcent),

- używanie różnych określeń do tego samego obrazka, przedmiotu, zdarzenia itp.,

- powtórzenia,

- opisywanie słów słowami,

- czekanie, zbliżanie się do dziecka, spoglądanie wyczekująco (zawsze należy dać dziecku czas na „przetworzenie informacji” i odpowiedź),

- mówienie, nie zważając, czy dziecko patrzy na nas, czy jest zajęte jakimś działaniem,

- angażowanie rodziców do aktywnego udziału, do mówienia, udzielania odpowiedzi za dziecko itp. bez specjalnego zwracania się do nich,

- wykorzystanie różnych sposobów odwracania uwagi dziecka od ruchu ust, od nauki kanałem wzrokowym, a stałe powracanie do pozyskiwania informacji drogą słuchową.

\section{Podsumowanie}

Metoda Audytywno-Werbalna łączy potrzeby dzieci niedosłyszących z osiągnięciami nauki, techniki i medycyny w zakresie leczenia i rehabilitacji różnego stopnia ubytków słuchu. Wypełnia ją zestaw reguł, ale organizuje kreatywność, współpraca z rodzicami, wyraźny podział ról i zadań. Postępowanie zgodne z zasadami Metody Audytywno-Werbalnej pozwala tworzyć efektywne programy postępowania, obserwować, diagnozować i oceniać rozwój dziecka. Wymaga zmiany przyzwyczajeń, które powodują, że rodzice przychodzą na zajęcia, żeby albo patrzeć, albo odpocząć. Metoda ta sprawia, że można czerpać ogromną satysfakcję z działań zawodowych jako osoby prowadzącej rehabilitację słuchu i mowy dziecka oraz pozwala wzbudzić w rodzicach wiarę w powodzenie ich działań, pokazać sposób na efekt i radość, jeśli tylko zaakceptują określone zasady i wprowadzą je w codzienne życie dziecka i całej rodziny.

\section{Piśmiennictwo:}

1. Urbantschitsch V. Auditory Training for Deaf Mutism and Aquired Deafnes (S.R. Silverman, Trans.). Washington: Alexander Graham Bell Association for the Deaf; 1982.

2. Estabrooks W i wsp. Materiały dla uczestników Warsztatów Naukowo-Szkoleniowych dla Terapeutów Mowy „Listening for Life. Auditory-Verbal Therapy: Principles into Practice", 2008-2009.
3. Estabrooks W. 50 FAQ About AVT. Washington: Alexander Graham Bell Association for the Deaf and Hard of Hearing, Inc.; 2001, 156-61. 